\title{
Energy Efficient Control by the Group of Oil Pumping Stations Operation
}

\author{
Kaniuk G. I., Mezeria A. Yu., Kniazeva V. N., Fursova T. N., Blyznychenko E. N. \\ Ukrainian Engineering Pedagogics Academy \\ Kharkov, Ukraine
}

\begin{abstract}
This work is devoted to intensification of the power efficiency of computerized systems of control by the pumping units group of oil pumping stations of the main lines. The criterion of the energy efficiency is a minimum total energy loss. The goal set can be reached by the development of algorithms of the energy efficient control. The most important scientific result based on the identification of the mathematical models of the objects controlled is the efficient algorithm for controlling the group of oil pumping units. It allows determining in real time the operation modes of separate pumping units, upon which the total energy losses will be minimal. The significance of the results obtained consists in the energy losses decrease across the main oil pipeline during the combined control by the pumping units groups. Their practical significance consists in decreasing the cost of oil transportation at the expense of decreasing the energy consumed by the pumping units. The main stages of plotting the modes maps were presented of the efficient operation of the pumping units based on the definition of the necessary rotation frequencies and positions of the regulating valves. Experimentally was performed the analysis of the operation modes of the pumping unit using different methods for productivity regulation, and their comparative energy efficiency was shown. The experimental data extrapolation was carried out, and, on its basis, the possible economic effect was determined brought by the use of the energy-conserving systems of the controlling the group of pumping systems.
\end{abstract}

Keywords: pump, oil-pumping station, computerized system of control, energy saving.

DOI: https://doi.org/10.52254/1857-0070.2021.4-52.02

UDC: 622.276-054:006.44(043.3)

\section{Dirijare eficientă din punct de vedere energetic pentru grupul instalațiilor de pompare la stațiile de pompare a țițeiului}

Kanyuk G.I., Mezerya A.Yu., Knyazeva V.N., Fursova T.N., Bliznichenko E.N.

Academia Ucraineană de Inginerie și Pedagogică

Harkov, Ucraina

Rezumat. Scopul lucrării constă în creșterea eficienței energetice a sistemelor automate de didrijare pentru un grup de instalații de pompare (IP) la staţiile ale stațiilor de pompare a țiţeiului (SPȚ) prin conductele magistrale de transport. Criteriul de eficiență energetică a sistemului de dirijare dezvoltat este pierderile totale minime de energie în conducta magistrală de transport țiței, păstrând volumele de transportare a țiţeiului. Acest obiectiv este atins prin elaborarea algoritmilor pentru comanda eficientă din punct de vedere energetic a unui grup de instalații de pompare la stațiile de pompare a țiţeiului. Cele mai importante rezultate științifice: în baza identificării modelelor matematice ale obiectelor de dirijare (instalații de pompare), a fost propus un algoritm eficient de dirijare al unui grup de instalații pompare la stațiile de pompare a țițeiului, care face posibilă determinarea regimurilor de funcționare în timp real ale unităților de pompare luate aparte (valorile frecvenței de rotație a pompelor dirijate și poziția supapelor de reglare) la care pierderile totale de energie în conducta magistrală de transport țiței vor fi minime. Semnificația rezultatelor obținute constă în reducerea pierderilor de energie în conducta principală de țiței cu controlul combinat al unui grup de unități de pompare ale stațiilor de pompare a țițeiului. Semnificația practică a rezultatelor constă în reducerea costului transportului petrolului prin reducerea puterii consumate de unitățile de pompare. Sunt prezentate principalele etape ale construcției hărților de regim (dependența parametrilor de intrare controlați ai obiectului de control de parametrii de ieșire necesari) ale funcționării efective a unităților de pompare ale stațiilor de pompare a țițeiului.

Cuvinte-cheie: pompă, stație de pompare a petrolului, sistem de control automat, economisire de energie.

Энергоэффективное управление группой насосных установок нефтеперекачивающих станций Канюк Г.И., Мезеря А.Ю., Князева В.Н., Фурсова Т.Н., Близниченко Е.Н.

Украинская инженерно-педагогическая академия

Харьков, Украина

Аннотация. Цель работы заключается в повышении энергетической эффективности автоматизированных систем управления группой насосных установок (НУ) нефтеперекачивающих станций (НПС) магистральных нефтепроводов. Критерием энергетической эффективности разработанной системы управления является минимум суммарных потерь энергии в магистральном 
нефтепроводе при сохранении необходимых объемов транспортировки нефти. Поставленная цель достигается за счет разработки алгоритмов энергосберегающего управления группой насосных установок нефтеперекачивающих станций. Наиболее существенные научные результаты: на основе идентификации математических моделей объектов управления (насосные установки) предложен эффективный алгоритм управления группой насосных установок нефтеперекачивающих станций, позволяющий в реальном времени определять режимы работы отдельных насосных установок (значения частот вращения регулируемых насосов и положения регулирующих задвижек), при которых суммарные потери энергии в магистральном нефтепроводе будут минимальны. Значимость полученных результатов состоит в снижении потерь энергии в магистральном нефтепроводе при комбинированном управлении группой насосных установок нефтеперекачивающих станций. Практическая значимость результатов состоит в снижении себестоимости транспортировки нефти за счет снижения мощности, потребляемой насосными установками. Приведены основные этапы построения режимных карт (зависимость входных регулируемых параметров объекта управления от требуемых параметров на выходе) эффективной работы насосных установок нефтеперекачивающих станций на основе определения необходимых частот вращения регулируемых насосов и положений регулирующих задвижек. Экспериментально проведен анализ режимов работы насосной установки при различных способах регулирования производительностью (частотное, дроссельное и комбинированное) и показана их сравнительная энергетическая эффективность. Выполнена экстраполяция экспериментальных данных, и на её основе определен возможный экономический эффект от внедрения энергосберегающих систем управления группой насосных установок нефтеперекачивающих станций магистральных нефтепроводов.

Ключевые слова: насос, нефтеперекачивающая станция, автоматизированная система управления, энергосбережение.

\section{INTRODUCTION}

The share of oil and gas in the energy balance of industrially developed countries is about 75$80 \%$. Regardless of high efforts made in using the traditional and renewable sources of energy, this situation will remain unchanged for the nearest decades.

The necessity of transportation of significant volumes of oil and gas resulted in the intense development of the pipeline service as the most efficient economically [1].

The Ukraine is a powerful transiting channel of oil and gas. The Ukraine main oil line system includes 19 oil pipelines with a diameter of 1220 $\mathrm{mm}$ and total length of about $4800 \mathrm{~km}$ (e. g., Germany - $3380 \mathrm{~km}), 51$ oil pumping station (OPS), whose operation is ensured by 176 pumping units at a unit productivity to 12500 $\mathrm{m}^{3} / \mathrm{h}$. The overall electric power of the electric drives is around $360000 \mathrm{~kW}$. The system discharge capacity is $114 \mathrm{mln} \mathrm{t} / \mathrm{year}$ at the input and over $56 \mathrm{mln} \mathrm{t} / \mathrm{year}$ at the output. The total nominal capacity of eleven reservoir parks of the main oil pipes system is over $1 \mathrm{mln} \mathrm{m}^{3}$.

Oil transportation requires substantial energy consumption to drive the pump units of the oil pumping stations [2-4]. In this context, the urgent problem is the energy consumption decrease using the development and implementation of the energy saving systems of automatic regulation (SAR) of oil pumping units, which are component parts of the complex systems of the computerized control (SCC) for the oil transportation. They ensure the maximum value of the coefficient of efficiency (CEV) of the units by means of the optimal regulation of the rotation frequency.

The increase in the efficiency of the pumping units of the oil pumping stations is an important and urgent technical economic problem for the improvement of the technical economic characteristics of the main oil lines and for reducing the oil transportation cost.

In this way, this research is aimed at increasing energy efficiency of the pumping station units operation by improving the control systems, which ensure the minimum energy losses during the oil transportation.

The objects of the study are the processes of enhancing the operation efficiency of the pumping units of the oil pumping stations under normal modes of exploitation.

The objects of the research are scientific methods and technical means for the decreasing the energy losses in the oil transportation process under normal exploitation modes of the pumping units.

\section{ANALYSIS OF RECENT RESEARCHES AND PUBLICATIONS}

The research and optimization of the control systems of the main oil lines are performed by an appreciable quantity of European and world research teams. The design features and mechanics of the pumping units are studied 
fairly thoroughly. The advanced model pumping units with the improved technical economic characteristics are used successfully in all spheres of industry [5-8].

Much attention is given to the pumping units regulation [8-20]. The energy efficiency of the pumps is shown to depend above all on the regulation method selected and on the network characteristics they work for.

High success was achieved in the development of mathematical models of the elements and pumping units joint connections, including the pumps of the oil pumping stations [21-29].

At the same time, at present, the universal scientific methods and technical solutions are almost absent, which would guarantee the existence of the OPS operation energy efficient modes over the entire range of the normal modes of exploitation [16, 26].

The analysis performed set the research problem consisting in improving the energyconserving systems of control by the pumping units of the oil pumping stations of the main oil lines, developing the efficient algorithms to ensure minimum energy losses in the oil pipeline upon maintaining the technological parameters.

\section{RESEARCH METHODOLOGY}

Analysis of the existing normative and methodical support in creation the systems of control by the pumping units of the main oil pipelines showed that at present in the normative-technical and normative methodical documentation, the requirements as to the creation and exploitation of the systems of control by the main oil pipelines that ensure maximum operation efficiency of the pumping units and maintain their action at the coefficient of efficiency highest levels, are not quite fully formulated.

The main oil pipeline is a complicated structure, which consists of separate oil pumping stations with pumping units of various power (Fig. 1).

The crucial issue is the method for the pumps regulation. The most promising is the frequency regulation principle $[15,27]$. Unlike other methods, it has minimum energy losses for the oil transportation. In addition, due to the possibility of smooth regulation, it considerably improves startability and exploitation characteristics of the pumps and extends their service life. At the same time, the great variety of the regulation methods and the optimization variants of the operation modes of the main oil pipelines systems makes it possible to conclude a substantial variability of the modes selection criteria [11].

The developed functional schemes of the pumping units as the objects of control (Fig. 2), can be the basis for creation consistent solutions, i.e., the system of control by any pump of the main oil pipeline can be characterized using the following set of vectors:

- input parameters (regulation parameters)

$$
\vec{X}_{\text {input }}=\vec{X}_{\text {input }}^{\text {reg }}+\vec{X}_{\text {input }}^{\text {unreg }},
$$

including unregulated $\vec{X}_{\text {input }}^{\text {unreg }}$ and regulated $\vec{X}_{\text {input }}^{\text {reg }}$;

- output parameters (parameters controlled at the output ) $\vec{X}_{\text {output }}$;

- pump internal parameters $\vec{X}_{\text {int }}$;

- environmental factors (periodic and occasional)

$\vec{\xi}$;

- energy (power) loss parameters $\vec{X}_{\text {loss }}$.

The input parameters can include alternatives such as the position of the regulating valve $x_{r v}$, the pump unit rotation frequency $n$, and the blade angle of rotation $\alpha_{b l}$.

These and other parameters are regulated by the executing mechanisms EM according to the algorithm, which is being formed in the EM regulator. The output parameters include the values of pressure $(P)$ and consumption $(Q)$ created by the pumping unit, the useful power $\left(N^{u s f}\right)$ and consumed power $\left(N^{\text {cons }}\right)$; as well as the pump coefficient of efficiency $(\eta)$. The vector of internal parameters $\vec{X}_{\text {int }}$ includes design characteristics of the pumping unit and hydraulic circuit, which the pumping unit works for. The vector of environmental factors $\vec{\xi}$ includes eventual temperature changes and other environmental parameters in the process of exploitation. The major intended purpose of the regulation principle proposed is determination of real ratios for the controlled input parameters, which ensure the value of the minimum energy losses throughout the entire normal exploitation (with any vector values of the output parameters $\vec{X}_{\text {output }}$ :

$$
\vec{X}_{\text {input }}^{\text {reg }}=f_{\text {reg }}\left[\vec{X}_{\text {output }} ; \vec{X}_{\text {input }}^{\text {unreg }} ; \min \left\{\vec{X}_{\text {loss }}\right\}, \vec{\xi}\right]
$$




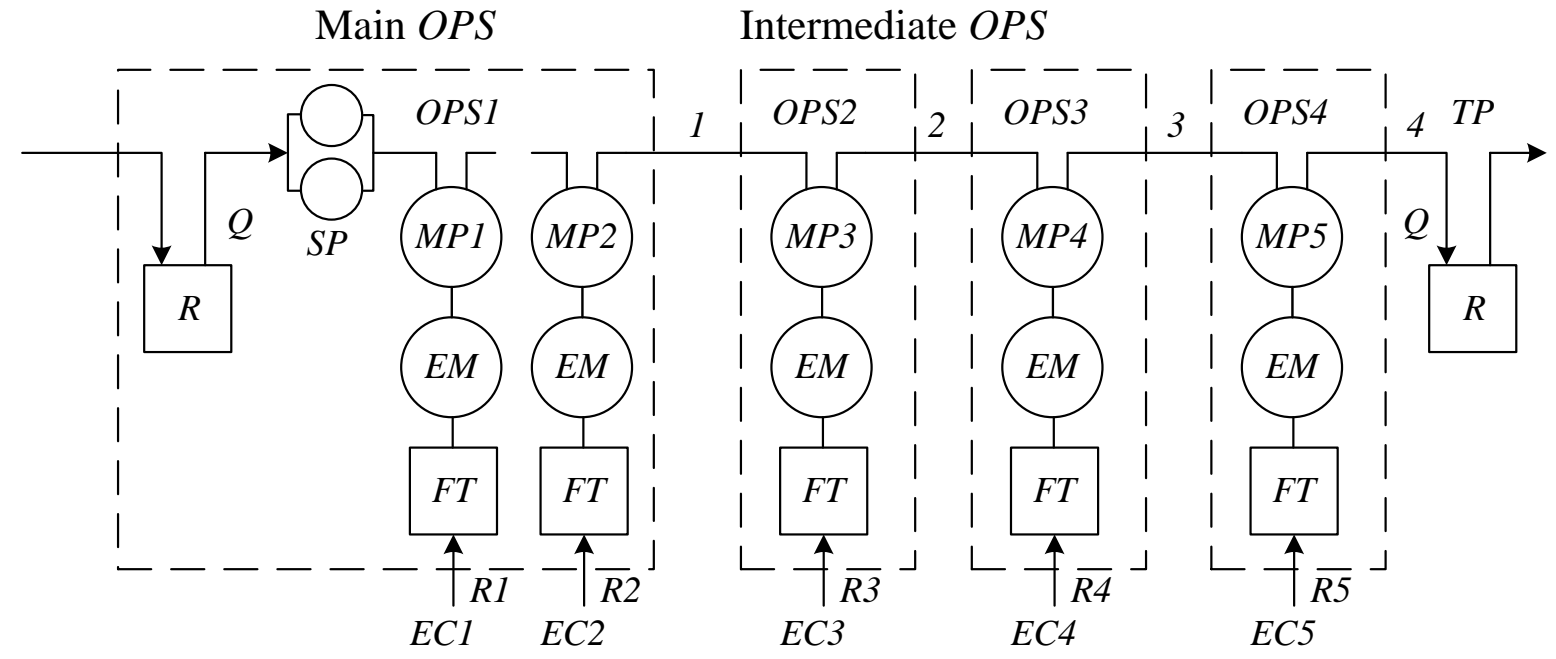

OPS - the oil pumping station, $\mathrm{R}$ - the regulator, $\mathrm{MP}$ - the main pump, EM - the electric motor, FT the frequency transformer, EC - the electric circuit, TP - the terminal point, SP - the start-up pump.

Fig. 1. Principal scheme of oil pumping system.
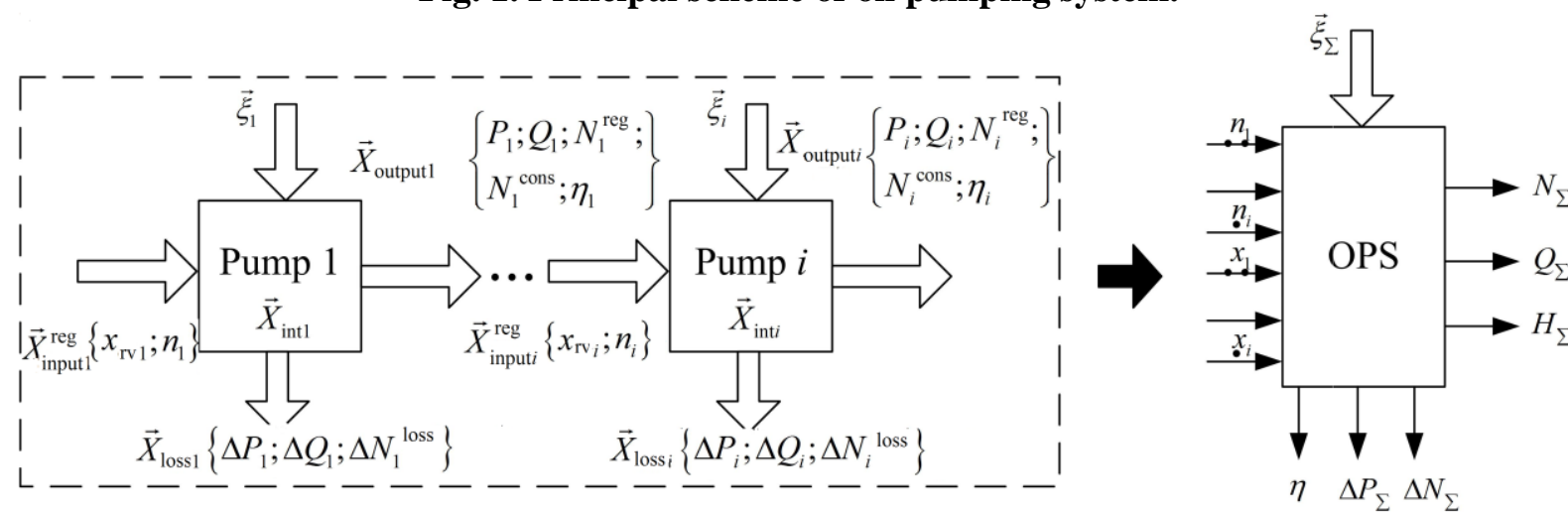

Fig. 2. Functional schemes of pumping units of oil pump lines as the object of control.

Generally, the function of the energy losses in the pumping unit is determined by the sum of mechanic $E_{\text {mech }}$, hydrogasdynamic $E_{g d}$, thermal $E_{t}$ and electric $E_{e l}$ losses in certain elements and processes occurring in the pumping unit. It can be represented as follows:

$$
\left\{\begin{array}{l}
\Delta E=\Delta E_{\text {mech }}+\Delta E_{g d}+\Delta E_{t}+\Delta E_{e l} ; \\
\Delta E=\sum_{i=1}^{n}\left(k_{d f r} \cdot F_{i}+k_{l f r} \cdot V_{i}\right) \cdot \Delta l ; \\
\Delta E_{g d}=\sum_{j=1}^{m}\left(\lambda_{j} \frac{l_{j}}{d_{j}}+\varsigma_{l j}\right) \cdot \frac{V_{j}^{2}}{2 g} \cdot G_{j} ; \\
\Delta E_{t}=\sum_{q=1}^{k} K_{h t q} \cdot \Delta T_{q} \cdot S_{q} \cdot t_{q} ; \\
\Delta E_{e l}=\sum_{r=1}^{l} I_{r}^{2} \cdot R_{r} \cdot t_{r},
\end{array}\right.
$$

where $n, m, k, l$ is the quantity of significant mechanic, hydrogasdynamic, thermal, electric processes and elements in the pumping unit; $F$ is the external load; $V$ and $G$ are the rate of motion and oil weight; $k_{\text {dfr }}$ and $k_{\text {lfr }}$ are the coefficients of dry and liquid frictions; $I$ is the current intensity; $\lambda$ and $\varsigma_{\mu}$ are the coefficients of friction and local hydraulic resistances; $K_{h t}$ is the heat transfer coefficient; $\Delta T$ is the temperature driving force; $S$ is the heat transfer area; and $t$ is the time of process.

Total energy losses in the OPS pumps depend on the oil consumption and pumps' rotation frequency:

$$
\Delta N=\sum_{i=1}^{n}\left(\begin{array}{l}
A_{Q_{2 i}} Q_{p i}^{2}+A_{n_{2 i}} \cdot n_{i}^{2}+A_{Q i} Q_{p i}+\ldots \\
+A_{n_{i}} \cdot n_{i}+A_{Q_{n i}} Q_{p i} \cdot n_{i}+C_{i}
\end{array}\right),
$$

or recalculating for the position of the regulation valves: 


$$
\Delta N=\sum_{i=1}^{n}\left(\begin{array}{l}
A_{l o s s_{i}}^{n 2} \cdot n_{i}^{2}+A_{l o s s_{i}}^{n} \cdot n_{i}+ \\
+A_{l o s s_{i}}^{x_{r} 2} \cdot x_{r v_{i}}^{2}+A_{l o s s_{i}}^{x_{r v}} \cdot x_{r v_{i}}+ \\
+A_{l o s s_{i}}^{x_{r v} n} \cdot x_{r v_{i}} \cdot n_{i}+A_{l o s s_{i}}^{0}
\end{array}\right)
$$

where coefficients $A$ define the dependence of the energy losses on the square of rotation frequency $A_{l o s s_{i}}^{n 2}$, rotation frequency $A_{l o s s_{i}}^{n}$, the square of position of the regulation valve $A_{l_{\text {loss }} s_{i}}^{x_{v}{ }^{2}}$, the position of the regulation valve $A_{l o s s_{i}}^{x_{r v} 2}$, the product of rotation frequency by position of the regulation valve $A_{l o s s_{i}}^{x_{r} n}$ and constant component $A_{\text {loss }}^{0}$, which is independent of the regulated parameters. The values of coefficients $A$ can be determined by the experimental data resulting from approximation of full-scale and current exploitation characteristics with respect to dependences (5).

In dependences (5) $A_{\eta i}$ is the dependency ratio of coefficient of efficiency of the $i$-th pump on the oil consumption at a fixed viscosity value; $A_{N i}$ is the dependency ratio of the consumed energy of the $i$-th pump on the oil consumption at a fixed viscosity value; $B_{\eta i} B_{N i}$ are the dependency ratios of the coefficient of efficiency and consumed energy of the $i$-th pump on the rotation frequency; and $C$ are the constant components of relevant characteristics.

$$
\begin{aligned}
& \left\{\begin{array}{l}
A_{Q_{2} i}=-A_{\eta i} A_{N i} ; \\
A_{n_{2} i}=-B_{i n} B_{N i}
\end{array}\right. \\
& \left\{A_{Q i}=\left(A_{N i}-A_{\eta i} C_{N i}-C_{\eta i} A_{N i}\right) ;\right. \\
& A_{n i}=\left(B_{N i}-B_{\eta i} C_{N i}-C_{\eta i} B_{N i}\right) \text {; } \\
& A_{Q n i}=-\left(A_{\eta i} B_{N i}+B_{\eta i} A_{N i}\right) \text {; } \\
& C_{i}=\left(1-C_{\eta i}\right) \cdot C_{N i} \text {; } \\
& \left(A_{\text {loss }_{i}}^{n 2}=A_{Q_{2} i}\left(A_{Q_{p} i}^{n}\right)^{2}+A_{n_{2} i}+A_{Q_{n} i} A_{Q_{p} i}^{n} ;\right. \\
& A_{\text {lossi }}^{n}=2 A_{Q_{2} i} A_{Q_{p} i}^{n} C_{Q_{p} i}+A_{Q_{i}} A_{Q_{p} i}^{n}+A_{n i}+\ldots \\
& +A_{Q_{n} i} C_{Q_{p} i} \\
& A_{\text {loss }_{i}}^{x_{r v}{ }^{2}}=A_{Q_{2} i}\left(A_{Q_{p} i}^{x_{r v}}\right)^{2} \text {; } \\
& A_{l_{\text {los } s_{i}}}^{x_{v v}}=2 A_{Q_{2} i} A_{Q_{p} i}^{x_{r v}} C_{Q_{p} i}+A_{Q_{i}} A_{Q_{p} i}^{x_{r v}} ; \\
& A_{\text {loss }}^{x_{r} n}=4 A_{Q 2 i} A_{Q_{p} i}^{n} A_{Q_{p} i}^{x_{v v}}+A_{Q_{n} i} A_{Q_{p} i},
\end{aligned}
$$




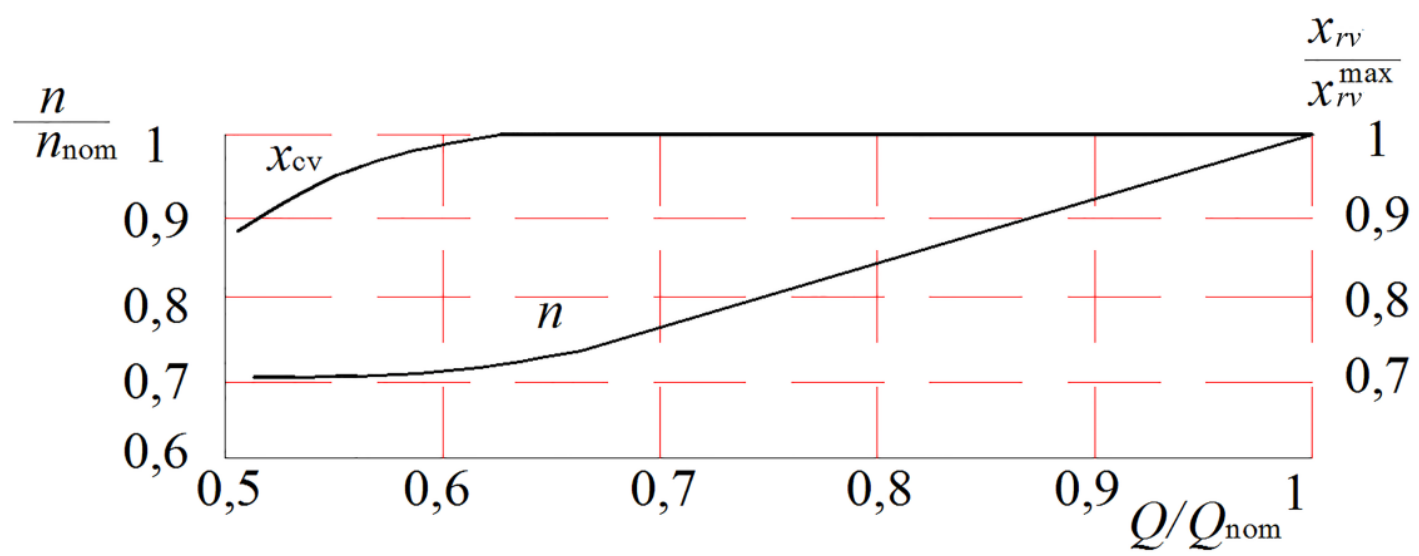

Fig. 3. Mode map of the energy-efficient operation of OPS pump.

In accordance with the developed and identified using the results of the full-scale experiment, data of mathematical models (29) and general concept of the energy efficient control (1), it is possible to obtain the generalized functional scheme of the system of automatized energy-saving control by the OPS units (Fig. 4).

This kind of control system contains blocks of pumping units reference models of separate OPS and the block of reference main oil pipeline as a whole, blocks of formation and determination of energy loss functions in the pumping units of the oil pumping system and blocks for minimum function comparison of the energy losses.

The experiments were performed using the laboratory operating unit equipped with facilities for frequency and throttle regulation of productivity.

The working characteristics plotted based on the measurements and calculations for the centrifugal pump 2K-6 (electric motor AO-42-2; $\left.\eta_{\mathrm{m}}=0.84\right)$ are shown in Fig. 5.

The decrease in the consumed power at the frequency method of control compared to the throttle method of control is as follows:

$$
\Delta N=N_{t h}-N_{f r} .
$$

Annual energy saving during the pumping unit operation for $7000 \mathrm{~h}$ per year (average calculation period), is:

$E K=\Delta N \cdot 7000=1000 \cdot 7000 \cdot 0,7=4900 \mathrm{kWh} .(12)$

where 0.7 is the mode coefficient.

The graphs of difference in the pump characteristics between the frequency and throttle controls are shown in Fig. 6.
The economic efficiency of the frequency control is defined based on the annual graph of the pump load and the system as a whole.

Thus, the yearly-average economy of energy is as follows:

$$
E_{a v}=\frac{1}{T} \int_{0}^{T} \Delta N_{i} \cdot t_{i} d t
$$

Under conditions of the uniform distribution of the load during calculation period in the range of (30-100) \% of the power, the energy economy is determined as following:

$$
E_{a v}=\frac{\Delta N_{30}+\Delta N_{100}}{2} T
$$

In this particular case, the decrease in the energy losses can be about $5000 \mathrm{kWh}$. The annual economy at tariff $\mathrm{c}=0.05 € / \mathrm{kWh}$, is 250 $€$.

Upon the overall electric power of the electric drivers of the Ukraine oil pumping stations being $360 \mathrm{kWh}$ and if that each third pump has a system of the frequency control, the annual economy of energy will be as following

$$
E_{\Sigma}=\frac{W_{a v} \cdot N_{\Sigma}}{3 N_{e x}}
$$

and may exceed $250 \mathrm{kWh}$.

That is, in money equivalent the annual economy will be over $12 \mathrm{mln}$. $€$. 
With the frequency drivers being mounted at annual profit will be over 15 mln. $€$. the increased number of pumps, the expected

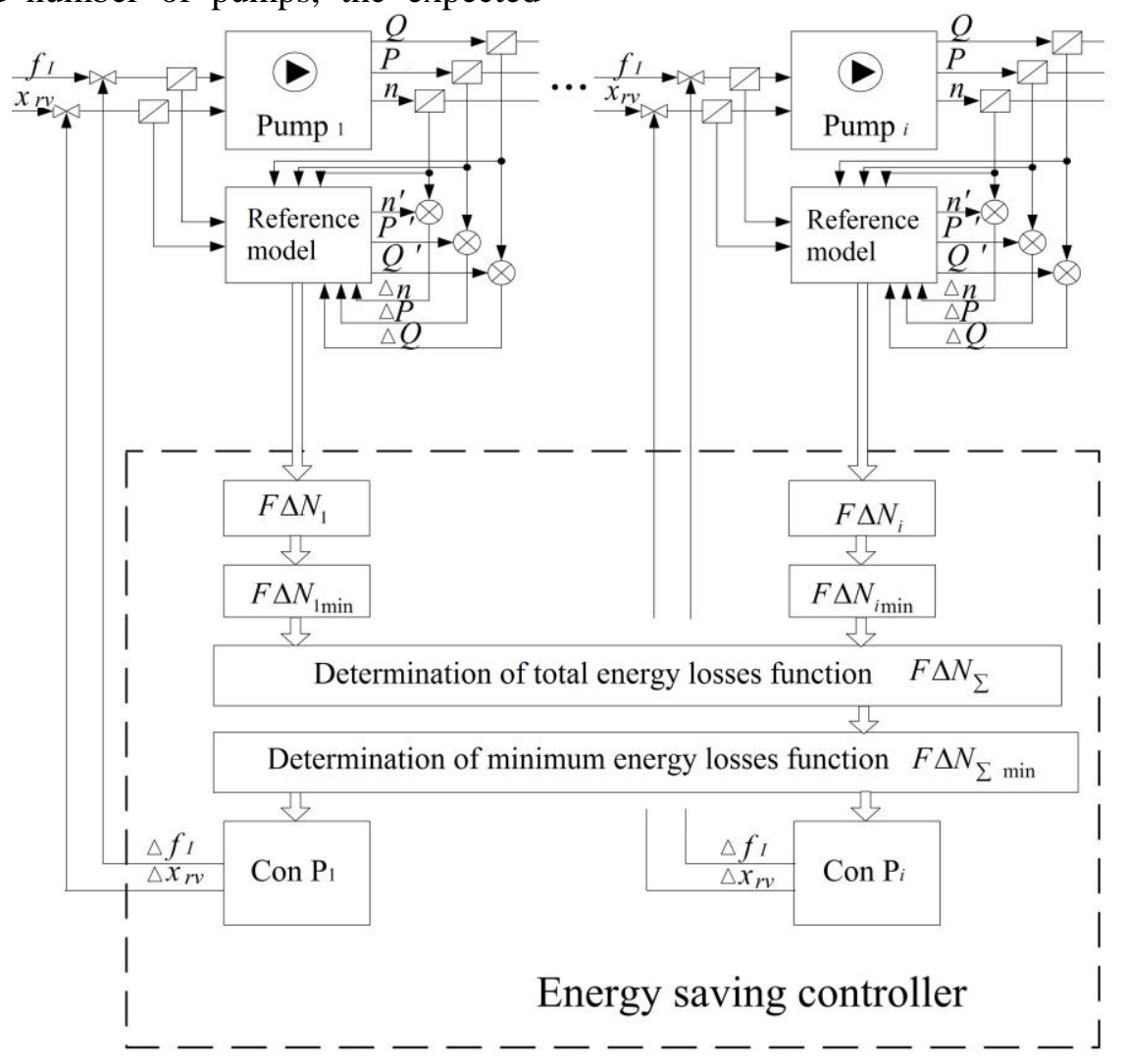

Fig. 4. Functional scheme of control by the OPS pump group.

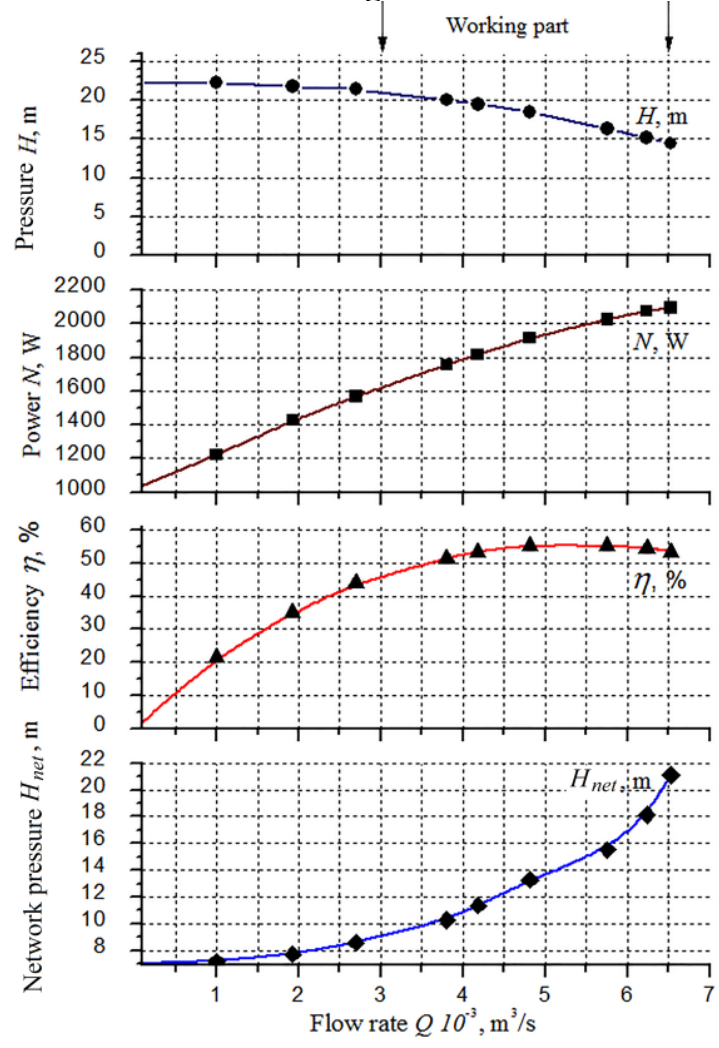

a)
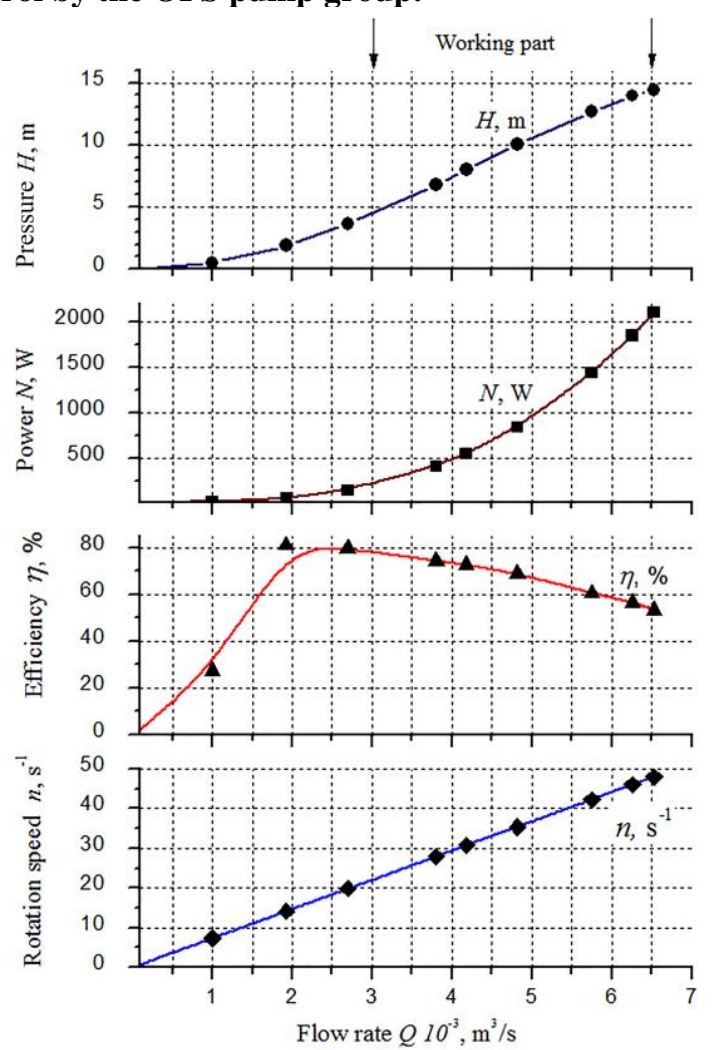

б)

a) throttle regulation; b) frequency regulation

Puc.5. Energy characteristics of 2K-6 pump. 


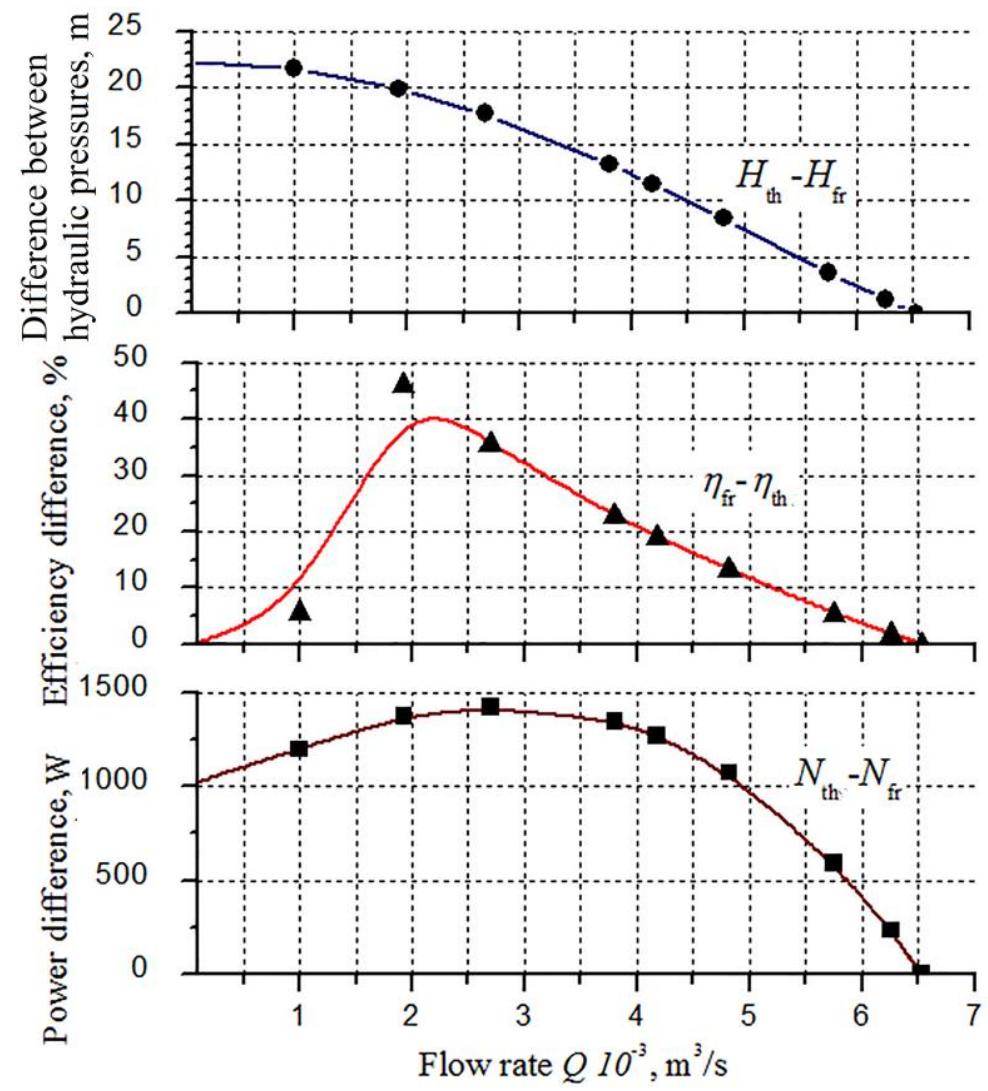

Fig. 6. Differences between energy characteristics of $2 \mathrm{~K}-6$ pump under frequency and throttle controls.

\section{CONCLUSIONS}

The scientific and practical results obtained allow the following inferences:

1. Further development was obtained by the algorithms of the systems of the energy-conserving control by the group of pumping units of oil pumping stations of the main oil pipelines, which ensure minimum energy losses throughout the total range during a normal exploitation.

2 . The generalized verified mathematical model of the OPS pumping units was proposed, and the main ratios for the determination of the main energy losses in the elements of the system of control were obtained. The analytical dependences between the major mode parameters of the OPS pumping units operation by the approximation of their experimental characteristics were obtained.

3 . The experiments of the modes of pumps' operation were carried out, and on their basis the identification was performed of the developed mathematical models. The extrapolation of the experimental results obtained on the Ukrainian active oil pumping stations under condition that each third pump is equipped with the system of frequency control, showed that the implementa- tion of the experimental results obtained and developments at the Ukrainian OPS can ensure the annual energy economy during oil transportation of the order of $400 \mathrm{mWh}$.

\section{REFERENCES}

[1] Wilson K.C., Addie G.R., Sellgren A., Clift R. Slurry Transport Using Centrifugal Pumps. 3th ed. New York, Springer Science+Business, 2006. $-441 \mathrm{p}$.

[2] Samolenkov S.V., Kabanov O.V. Determination of the mode working parameters of centrifugal pumps reducing the energy consumption during oil transportation. Scientific Reports on Resources Issues Freiberg: Technical University Bergakademie, 2012. pp. 260-263.

[3] API STD 610. Centrifugal Pumps for Petroleum, Petrochemical, and Natural Gas Industries, 12th Edition. Washington, DC, American Petroleum Institute, 2021. $233 \mathrm{p}$.

[4] Hart A. A review of technologies for transporting heavy crude oil and bitumen via pipelines. Journal of Petroleum Exploration and Production Technology, 2014, vol. 4, pp. 327-336. doi.org/10.1007/s13202-013-0086-6.

[5] Liu H. Pipeline [Encyclopedia Britannica]. Available at: https://www.britannica.com/technology/pipelinetechnology (accessed 14.06.2021). 
[6] Pozos-Estrada O., Sánchez-Huerta A., BreñaNaranjo J. A., Pedrozo-Acuña A. Failure Analysis of a Water Supply Pumping Pipeline System. Water 2016, vol 8(9), p.395. doi.org/10.3390/w8090395.

[7] Carmona-Paredes R.B., Pozos-Estrada O., Carmona-Paredes L.G., Sanchez-Huerta A., RodalCanales E.A., Carmona-Paredes G. Protecting a Pumping Pipeline System from Low Pressure Transients by Using Air Pockets: A Case Study. Water 2019, vol 11(9), p.1786. doi.org/10.3390/w11091786.

[8] Gromakov E. I., Rybakov E. A., Starikov D. P. [Automatic pressure control in the oil pipeline]. International Conference on Mechanical Engineering, Automation and Control Systems (MEACS). Tomsk, 2014, pp. 1-3 doi: 10.1109/MEACS.2014.6986845

[9] Perekrest A.L., Koren'kova T.V., Rod'kin D.I. Sistemy aktivnogo regulirovanija parametrov nasosnyh kompleksov [Active control systems of parameters of pumping complexes]. Kremenchug, 2011. $180 \mathrm{p}$.

[10] Shabanov V.A., Kabargina O.V., Pavlova Z.H. Snizhenie voln davlenija $\mathrm{V}$ nef-teprovode pri chastotno-reguliruemom jelektroprivode magistral'nyh nasosov [Reduction of pressure waves in an oil pipeline with a frequency-controlled electric drive of main pumps]. Vestnik Atyrauskogo instituta nefti $i$ gaza-Bulletin of the Atyrau Institute of Oil and Gas, 2011, no.1(24), pp. 71-76. (In Russian).

[11]Babenko I.A Udoskonalennja ta unifikacija metodiv zabezpechennja energoefektivnih rezhimiv roboti nagnital'nih ustanovok elektrostancij. Avtoref. Dis. kand. tehn. nauk [Improvement and unification of methods for ensuring energy-efficient operating modes of pumping units of power plants. Cand. techn. sci. diss.]. Harkiv, 2017. 28 p.

[12] Sokol E.I., Baru A.Ju., Shindnes Ju.L., Lukpanov Sh.K. Opyt razrabotki i vnedrenija preobrazovatelej chastoty dlja reguliruemogo elektroprivoda nasosnyh agregatov $\mathrm{MN}$ [Experience in developing and implementing frequency converters for adjustable electric drives of pumping units $\mathrm{MH}$. Elektrotehnika - Electrical engineering, 2004. no7, pp. 52 - 57. (In Russian).

[13] Bogdanov R.M. [Diagnostics of electricity consumption in power plants for oil transportation] Neftegazovoe delo, 2012, no.3. (In Russian). Available at: http://www.ogbus.ru/authors/ Bogdanov/Bogdanov_3.pdf. (accessed 22.05.2021)

[14] Gafarov R.R. Avtomatizirovannaja sistema opredelenija optimal'nogo rezhima raboty uchastka nefteprovoda. Avtoref. diss. kand.teh.nauk [Automated system for determining the optimal operating mode of an oil pipeline section. Cand. techn. sci. diss.]. Ufa, 2009. 19 p.
[15]Lazarev G.B. Chastotno-reguliruemyj elektroprivod nasosnyh i ventiljatornyh ustanovok [Frequency-controlled electric drive of pumping and fan units]. Silovaja jelektronika - Power electronics, 2007, no.3, pp. 41-48. (In Russian).

[16] Starikov D P, Rybakov E A, Gromakov E I. The pipeline oil pumping engineering based on the Plant Wide Control technology. IOP Conf. Series: Materials Science and Engineering. Tomsk, 2015, vol.81, pp.1-6. doi:10.1088/1757899X/81/1/012111

[17] Hashim A. Hussein, Abdzahraa J. Aleeby, Zahraa M. Mahdi. Improving the Performance of the Pump Station in Pipe Line Transportation System Using PLC Controller and Remote Monitoring. IOP Conf. Series: Materials Science and Engineering, Iraq, 2020, vol. 765, p.9. doi:10.1088/1757-899X/765/1/012050

[18] Bela Liptak. Crude Oil Pipeline Control. Available at: https://www.controlglobal.com/articles/2012/exp erts-crude-oil-pipeline-control/ (accessed 27.09.2012)

[19] Jacques Chaurette. Pump performance measurements. Available at: https://www.pumpfundamentals.com/download/p ump_performance.pdf (accessed 14.06.2021)

[20] Jacques Chaurette. Centrifugal pump specific speed primer and the affinity laws. Available at: https://www.pumpfundamentals.com/download/s pec_speed_primer.pdf (accessed 14.06.2021)

[21] Chertkov N.K., Barmenkov G.B., Meshkov B.B. Sistema modelirovanija energeticheskih ustanovok [Power plant simulation system]. Teploenergetika - Thermal power engineering, 2006, no5, pp. 62-65. (In Russian).

[22] Pan'ko M.A. Vybor matematicheskih modelej obekta upravlenija po eksperimental'nym dannym [Selection of mathematical models of the control object based on experimental data]. Teploenergetika - Thermal power engineering, 2006, no10, pp. 20-23. (In Russian).

[23] Mamedov A.I. [A simplified numerical method for calculating transient processes in the main oil pipeline when starting a pumping unit into operation] Problemy energetiki, 2007, no.2. (In Russian).

Available

at: http://www.science.gov.az/physics/

PowerEng/2007/v1article/art16.pdf (accessed 14.06.2021).

[24] Bachus L., Custodio A. Know and understand centrifugal pumps. Oxford, Elsevier Advanced Technology, 2003, 265 p.

[25] Xingtao Wang, Jian Zhang, Xiaodong Yu, Lin Shi, Wenlong Zhao, Hui Xu. Formula for selecting optimal location of air vessel in long-distance pumping systems. International Journal of Pressure Vessels and Piping, 2019, vol.172, pp.127133. doi: 10.1016/j.ijpvp.2019.03.029 
[26] De Marchis M., Fontanazza C., Freni G., Messineo A., Milici B., Napoli E., Notaro V., Puleo V., Scopa A., Energy recovery in water distribution networks. Implementation of pumps as turbine in a dynamic numerical model. Procedia Engineering, 2014, vol.70, pp.439-448. doi:10.1016/j.proeng.2014.02.049

[27] Juan Reca-Cardeña, Rafael López-Luque. Design Principles of Photovoltaic Irrigation Systems. Advances in Renewable Energies and Power Technologies, 2018, vol.1, pp. 295333.doi.org/10.1016/b978-0-12-812959-3.000095

\section{Information about authors.}
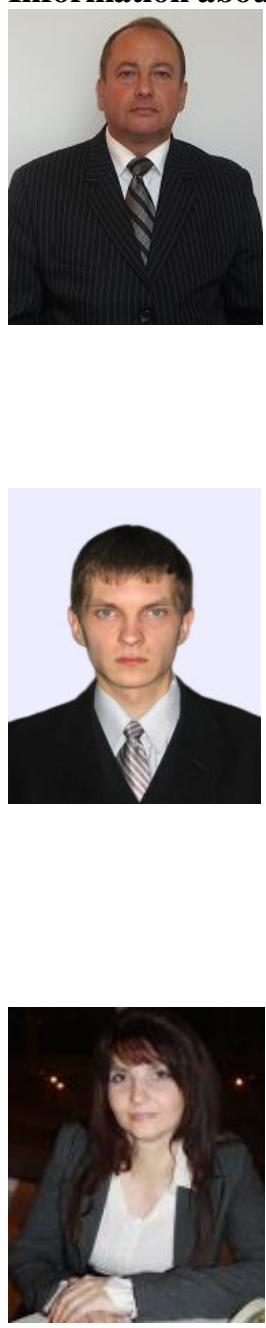

[28] Geoff Brown. Understand pump fundamentals for best efficiency. Available at: https://assets.markallengroup.com//articleimages/27341/Basics\%20of\%20pumps.pdf (accessed 14.06.2021)

[29] Nesbitt B. Handbook of Pumps and Pumping. 1th ed. Elsevier Science, 2006. 424 p. Available at: http://www.iqytechnicalcollege.com/Handbook\% 20of\%20Pumps\%20and\%20Pumping.pdf (accessed 14.06.2021)

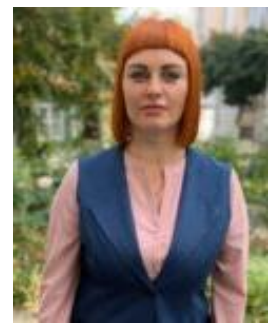

Kniazeva Victoria

Mykolaivna, Doctor of Philosophy (PhD), Senior Instructor of the Department of Automation, Metrology and Energy Efficient Technologies Ukrainian Engineering Pedagogics Academy, Kharkiv, Ukraine E-mail: vitok911@ukr.net

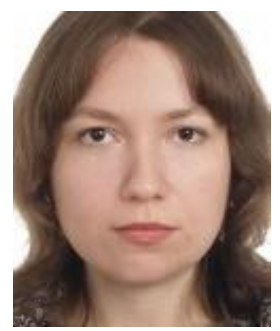

Fursova Tetiana

Mykolaivna, Candidate of Technical Sciences,

Associate Professor, Senior Lecturer of the Department of Automation, Metrology and Energy Efficient Technologies Ukrainian Engineering Pedagogics Academy, Kharkiv, Ukraine E-mail: tatiana2507@ukr.net

\section{Blyznychenko Olena} Mykolaivna, Doctor of Philosophy (PhD), Senior Instructor of the Department of Automation, Metrology and Energy Efficient Technologies Ukrainian Engineering Pedagogics Academy, Kharkiv, Ukraine E-mail: diana@ukr.net 